\title{
The effect of additives supplementation on the limitation of lipid and protein oxidation in dried snakehead fish (Channa striata)
}

\author{
Tran, B.L., Nguyen, V.M. and ${ }^{*}$ Tran, T.T. \\ College of Agriculture, Can Tho University, Campus 2, 3/2 street, Ninh Kieu District, Can Tho City, \\ Vietnam
}

\begin{abstract}
Article history:
Received: 15 August 2020

Received in revised form: 9 September 2020

Accepted: 24 September 2020 Available Online: 18 October 2020
\end{abstract}

\section{Keywords:}

Ascorbic acid,

Glycerol,

Oxidation,

Snakehead fish,

Sorbitol

DOI:

https://doi.org/10.26656/fr.2017.4(6).440

\begin{abstract}
The study was carried out to assess the effects of additives (glycerol and sorbitol) and the role of supplement rate of ascorbic acid on reducing lipid and protein oxidation in dried snakehead fish (Channa striata). The research results revealed that adding additives increased the amount of dry matter of the material, leading to a shorter drying process. The addition of glycerol and sorbitol at different ratios were the causes of the change of drying time and sulfhydryl index, peroxide value, TBARS index, salt content, color, and water activity level of the dried snakehead fish. Using 3\% glycerol combined with $4 \%$ sorbitol, the drying time was $26.21 \mathrm{hrs}$. Dried snakehead fish product had a salt content of $6.04 \%$, a water activity of 0.576 , a brightness of 43.90 , a peroxide value of $0.064 \mathrm{meq} / \mathrm{kg}$ lipid, a TBARS of $4.40 \mathrm{mg} \mathrm{MDA} / \mathrm{kg}$, a total sulfhydryl of $30.22 \mu \mathrm{mol} / \mathrm{g}$ protein, and an available sulfhydryl of $11.41 \mu \mathrm{mol} / \mathrm{g}$ protein. When ascorbic acid was added, the oxidation indexes of dried snakehead fish were significantly reduced; however, ascorbic acid showed a superiority at $0.04 \%$ with peroxide indices of $0.04 \mathrm{mEq} / \mathrm{kg}$ lipid, TBARS was $4.28 \mathrm{mg} \mathrm{MDA} / \mathrm{kg}$ a total sulfhydryl of $31.60 \mu \mathrm{mol} / \mathrm{g}$ protein and sulfhydryl available reached to $11.94 \mu \mathrm{mol} / \mathrm{g}$ protein. The difference between the experiment of adding ascorbic acid was even more significant after four weeks of storage when the dried snakehead fish was less lipid and protein oxidation.
\end{abstract}

\section{Introduction}

The snakehead fish (Channa striata) (Bloch, 1793), from the family Channidae, has a wide range of habitats ranging from rivers, swamps, ponds, canals, lakes, and land of rice fields. Their natural populations are extensively distributed across southern Asia (Hossain et al., 2008). Among Channa species, Channa striata collected from the wild in five locations in Southeast Asian countries have the highest level of within-species divergence (Adamson et al., 2010). In the Mekong Delta of Viet Nam, there are four species of Channa: Channa striata, Channa micropeltes, Channa lucius, and Channa gachua (Tran et al., 2013). Channa striata is a large snakehead species that is very common in the Mekong Delta. Fish is a source of food nutrients necessary and beneficial for human health, such as high protein, high unsaturated fatty acids in the lipid compositions (Hu et al., 2002). Fish meat is susceptible to oxidation due to its high content of unsaturated fatty acids (Sullivan and Budge, 2012), damaged by enzymatic hydrolysis and microbial growth (Uçak et al., 2011). Oxidation is the process of polyunsaturated fatty acids catalyzed by heat, light, and enzymes forming peroxides, aldehydes, ketones, and free radicals. Meanwhile, salting and drying were common methods to help preserve fish products and avoid rotten, corrupt, and unwanted changes after the fish die (Thorarinsdottir et al., 2004). The processing of dried food is lowering the water activity $\left(\mathrm{a}_{\mathrm{w}}\right)$, which have a longer shelf life and maintain a certain humidity (Barrett et al., 1998). Structured products dry, low organoleptic value reduces economic efficiency. The addition of moisturizing additives is being applied to reduce aw values and maintain food moisture because it denatures proteins and creates tighter structures in the material (Tomokazu, 2003). Glycerol is used to retain moisture, sweeten, and reduce aw (Nguyen and Tran, 2008). The oxidation of lipids will cause protein oxidation in the product. Therefore, the addition of antioxidants at a suitable concentration will limit the oxidation of fish meat, increase the duration of use and stable product quality (Serdaroglu and Felekoglu, 2005). However, antioxidants are used as prescribed, which cannot be used on some fish (Ladikos and Lougovos, 1990). Therefore, the study of additive and antioxidant 
supplementation in dried snakehead fish processing with low aw, limiting lipid and protein oxidation, improving product quality and sensibility.

\section{Materials and methods}

\subsection{Sample preparation}

Snakehead fish (Channa striata) were purchased from the Tra $\mathrm{Cu}$ district's farming areas, Tra Vinh province, Viet Nam. The weight of the fish was from 500 to $800 \mathrm{~g}$. Fish was alive, healthy, intact (not scratched), no defects, no infection, not parasitic, meet food processing requirements. Snakehead fish was stored in plastic containers with water and transported to the laboratory within $3 \mathrm{hrs}$ maximum. In the lab (Department of Food Technology, College of Agriculture, Can Tho University), fish have contained in a water tank at least $1 \mathrm{hr}$ before processing and analysis.

Snakehead fish was weighed before fainting volume and cut more domestic and blood discharge (discharge time of fish blood at least $10 \mathrm{mins}$ to separate blood type). Cut-out fish was converted to scales, gills, gill covers, organs, and heads (Tran et al., 2019). After that, the fish was filleted, take the fish meat and remove the fishbone.

\subsection{Experimental design}

2.2.1 Effect of combination ratios of sorbitol and glycerol on lipid and protein oxidation in dried snakehead fish

After the pre-treatment process, the snakehead fish was soaked in $12 \%$ sodium chloride solution (Tran et al., 2019). After $3 \mathrm{hrs}$ of brining, the fish was drained and weighed to determine the weight. Sorbitol was added to the brined fish with 5 levels of varying amounts of $0 \%$, $2 \%, 4 \%, 6 \%, 8 \%$ in combination with glycerol at 5 levels of $0 \%, 1 \%, 2 \%, 3 \%, 4 \%$ and mixed for $1 \mathrm{hr}$. Then, the fish was dried via hot air drying at $60 \pm 2^{\circ} \mathrm{C}$ until the moisture content is reduced $20 \%$. The drying times were recorded. Physicochemical analysis was performed on the dried fish. The best physicochemical analysis results of the dried fish were selected to perform the subsequent study.

2.2.2 Storage study of different concentrations of ascorbic acid additive on the limitation of lipid and protein oxidation in dried snakehead fish

Similarly, the snakehead fish was brined and determined its weight as explained in 2.2.1. Different concentrations of ascorbic acid $(0.02 \%, 0.03 \%, 0.04 \%$, $0.05 \%, 0.06 \%$ ) was added with $4 \%$ sorbitol and $3 \%$ glycerol into the brined fish and mixed for $1 \mathrm{hr}$. The fish was then dried via hot air drying at $60 \pm 2^{\circ} \mathrm{C}$ until the moisture content is reduced $20 \%$. The dried snakehead fish was packed in vacuum polyamide/nylon (PA plastic) and stored for a period of 4 weeks at room temperature $\left(28 \pm 2^{\circ} \mathrm{C}\right)$. At the initial storage week and each week of storage, physicochemical properties of the dried snakehead fish were performed.

\subsection{Physicochemical analysis}

Analysis of the approximate dried snakehead fish was determined according to the following methods: peroxide value was analyzed based on the method of Michael and Oscar (2003), sulfhydryl group value was analyzed based on the method of Ellman (1959), and Thiobarbituric acid reactive substances (TBARS) was based on the method of Lemon (1975) with a slight modification following the method by Nguyen and Nguyen (2013). The color value was measured using a colorimeter (NR200, China). L* values were determined as indicators of lightness. Mohr method was applied to determine salt content while the water activity was measured using a water activity measuring device (Hygropalm HP23-A Portable, Rotronic, Switzerland).

\subsection{Statistical analysis}

Using Statgraphics Centurion 16.2, Copyright (C) PP, USA, and Excel program, data were analyzed for the degree of variation and significance of difference based on the analysis of variance (ANOVA) to determine if significant differences $(p \leq 0.05)$ existed between treatments using Least Significant Difference (LSD). All experiments were carried out in triplicate.

\section{Results and discussion}

3.1 Effect of combination ratios of sorbitol and glycerol on lipid and protein oxidation in dried snakehead fish

The addition of sorbitol and glycerol at various concentrations led to the changing of drying time, color, water activity (aw), and the salt content in the product. The effect of sorbitol and glycerol on $\mathrm{a}_{\mathrm{w}}$, color, and drying time showed in Figures 1, 2, 3, and 4.

Figure 1 indicates the increase of glycerol and sorbitol content led to the reduction of drying time. The drying time was 29.90 hours to obtain the dried fish's suitable moisture content with the lowest food additive adding ( $1 \%$ glycerol or $2 \%$ sorbitol). It could explain that the moisture content in raw material reduced when adding food additive in processing. Sorbitol and glycerol formed an osmotic pressure that leads to the escape of water in the raw material. The product will obtain the suitable moisture content when increasing the amount of sorbitol and glycerol. 


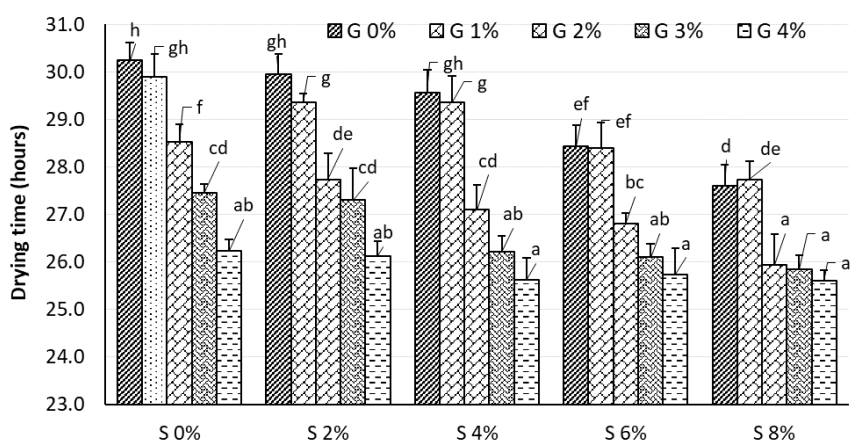

Figure 1. The change of drying time at various concentration of glycerol (G) and sorbitol (S) addition

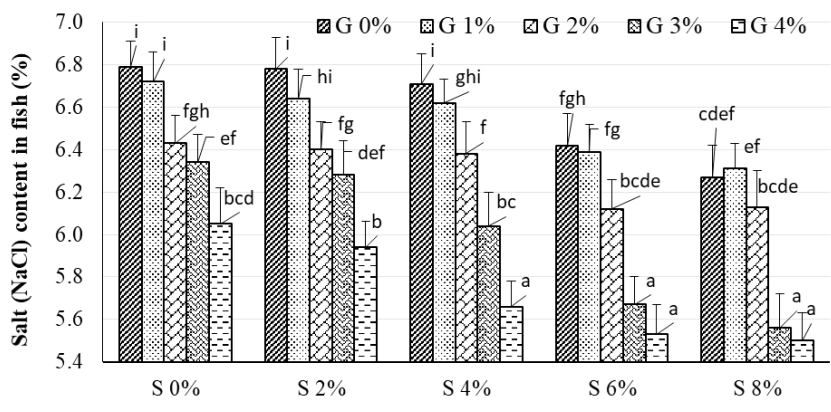

Figure 3. The effect of glycerol (G) and sorbitol (S) addition on salt content of dried fish

Furthermore, drying time reduction had a positive significance in preventing lipid and protein oxidation after drying. However, the effect of glycerol and sorbitol on technological factors also had a critical value. Dried snakehead fishes were added 2 to $4 \%$ glycerol combined with 4 to $8 \%$ sorbitol showed the lowest drying time and no statistically significant difference between samples. The addition of $3 \%$ glycerol and $4 \%$ sorbitol was used to shorten the drying time.

From the statistical analysis data in Figure 1, the lowest $\mathrm{a}_{\mathrm{w}}$ of dried snakehead fish obtained with 3 combination cases: using $2 \%$ glycerol with $6 \%$ sorbitol; $3 \%$ or $4 \%$ glycerol combined with $4 \%$ sorbitol. The result proved sorbitol's role with 6 hydroxyl groups and glycerol with $3(-\mathrm{OH})$ groups to form a hydrogen bonding with a water molecule, leading to a decrease in $a_{w}$. Park and Xiong (1997) investigated the effect of glycerol addition on dried Alaska Pollock (Theragra chalcogramma) on the maintenance of low $\mathrm{a}_{\mathrm{w}}$ and high moisture content of the product, leading to improve the structure of the product. Iseya et al. (2000) proved that sorbitol had a positive efficiency in moisture movement and texture change of fish and squid muscle during the salted and dried process. However, the glycerol addition was to form a moist surface product and reduce aw when compared with sorbitol addition. Furthermore, the addition of solute was the main reason for lowering salt concentration in the product (Figure 3). It can explain that the connection between glycerol and sorbitol with water in the product led to the competition with salt and

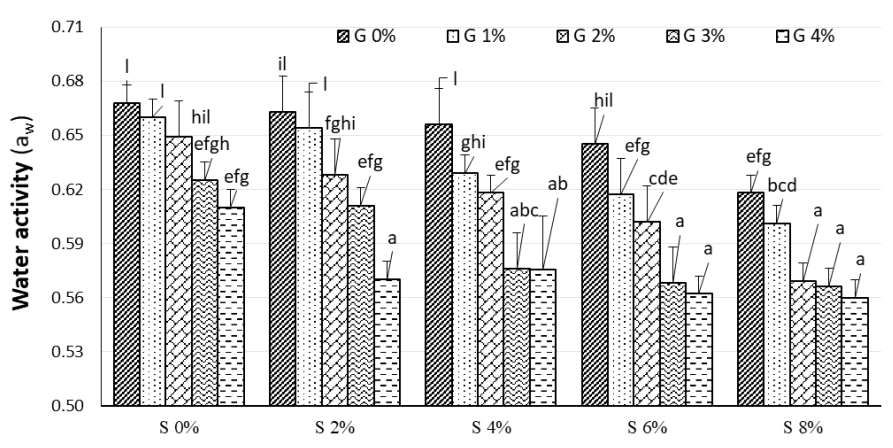

Figure 2. The effect of glycerol $(\mathrm{G})$ and sorbitol (S) addition on water activity of dried fish

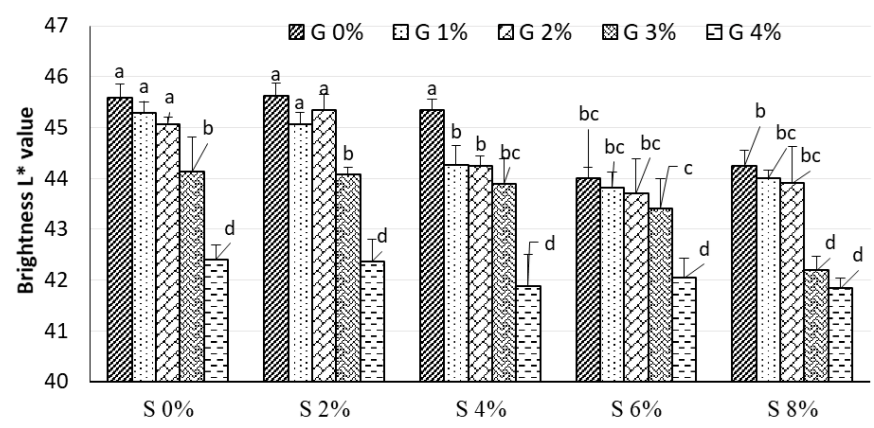

Figure 4. The effect of glycerol (G) and sorbitol (S) addition on the brightness ( $\mathrm{L}^{*}$ value) of dried fish

the changing of dissolved matter composition in dried fish.

Figure 4 shows the $L^{*}$ value degradation with the increase of dissolved matter addition. The brightness of dried fish was affected by glycerol addition at various 1 , 2,3 , and $4 \%$ concentrations. At the same time, sorbitol is the colorless compound and does not join to the browning reaction. Chanasattru (2008) explained that the interaction of dissolved matter compositions and protein, glycerol, increased gravity between protein molecules and led to the color changing of the product. The protein was challenging to denature by heating; these molecules were still active and had a gel-forming ability, leading to the product's brightness maintenance. However, sorbitol had not to gel-forming ability with protein and reducing the brightness of the product.

The influence of sorbitol and glycerol on peroxide value, sulfhydryl value was presented in Figures 5, 6, 7, and 8 .

The results showed that peroxide value decreased with increasing of sorbitol and glycerol concentration. Specifically, after drying to the permanent moisture content of $20 \%$, the dried fish product showed the lowest of peroxide value, TBARS at the glycerol and sorbitol concentration of 4 and $8 \%$, respectively, while the control sample (no glycerol and sorbitol addition) showed highest of these values. The highest of sulfhydryl value at $4 \%$ glycerol and $8 \%$ sorbitol. It can explain that fish lipids contained many unsaturated fatty 


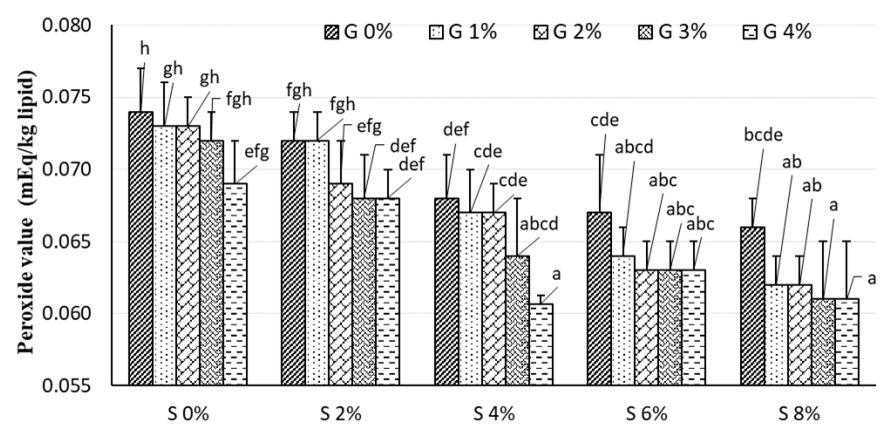

Figure 5. The effect of glycerol (G) and sorbitol (S) addition on peroxide value of dried fish

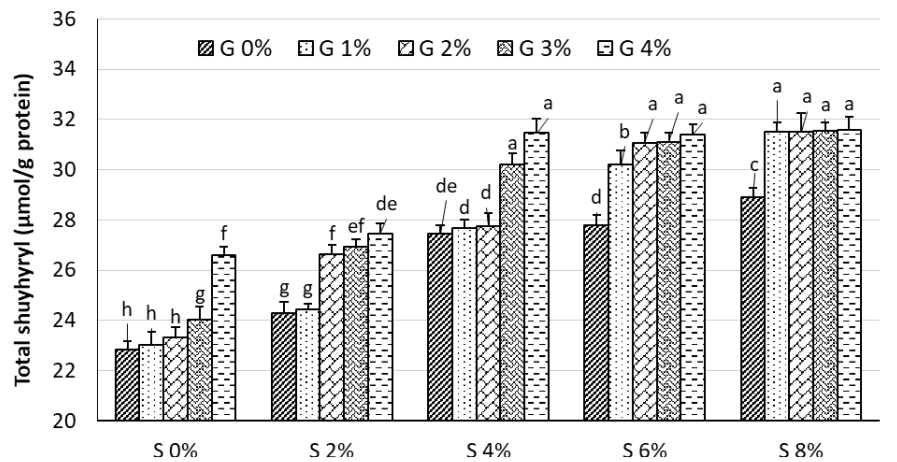

Figure 7. The effect of glycerol $(\mathrm{G})$ and sorbitol $(\mathrm{S})$ addition on total sulfhydryl group

acids leading to lipid oxidation during processing and preservation (Rao and Bandyopadhyay, 1983). However, the addition of glycerol and sorbitol had affected to shorten the drying time by protein denaturation ability, to form a tight structure and reduce the free water content (Fennema, 1996) and lead to the limitation of lipid oxidation.

In general, the combination of $3 \%$ glycerol and $4 \%$ sorbitol was helped to form the best-dried fish. The reduction of brightness was not different from the sample use only sorbitol decreased $\mathrm{a}_{\mathrm{w}}$ leads to prevent microorganism activity and retard lipid and protein oxidation. However, lipid oxidation reaction has still happened, especially the fat cells concentrated in the fish surface to affect the oxidation agents during the drying process. Therefore, the investigation of lipid antioxidants to retard lipid and protein oxidation was necessary.

\subsection{The influence of different concentrations of ascorbic} acid addition on the limitation of lipid and protein oxidation in dried snakehead fish storage

In this experiment, the influence of different concentrations of ascorbic acid addition in 3\% glycerol combined with $4 \%$ sorbitol to physicochemical properties of dried snakehead fish was performed during the storage period (until 4 weeks).

Tables 1, 2, and 3 present ascorbic acid's effect on the lipid and protein oxidation values. Table 1 shows that ascorbic acid addition formed a positive impact on the reduction of lipid oxidation. The peroxide value of all

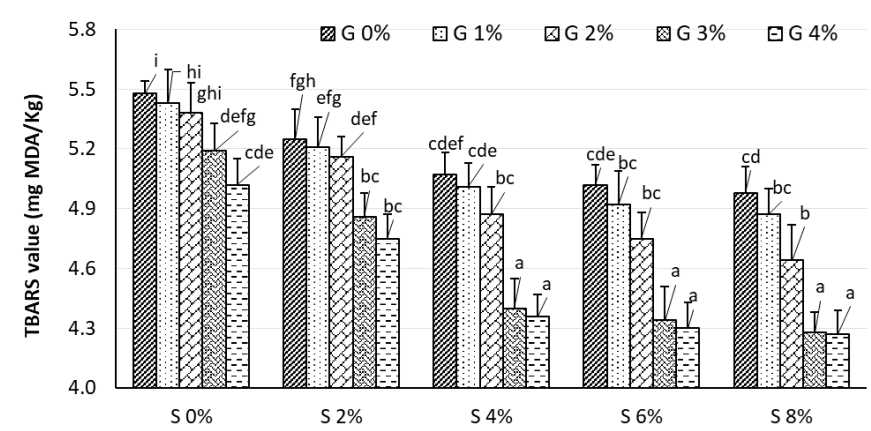

Figure 6. The effect of glycerol $(\mathrm{G})$ and sorbitol (S) addition on TBARS of dried fish

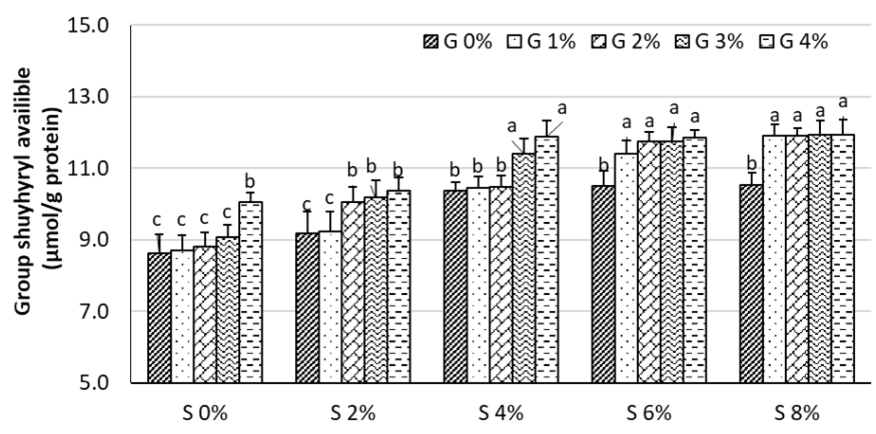

Figure 8. The effect of glycerol (G) and sorbitol (S) addition on available sulfhydryl group

samples decreased compared to the control sample (no oxidation addition) during 4 weeks of storage. Furthermore, peroxide value decreased with increasing of ascorbic acid from 0.02 to $0.04 \%$. However, ascorbic acid concentration increased to 0.05 and $0.06 \%$, which did not observe peroxide value degradation. Research results also showed that the addition of $0.02 \%$ ascorbic acid helped reduce the peroxide value for 3 weeks of dried snakehead storage.

However, the oxidation was stopped at the formation of peroxide and hydroperoxide and formed volatile carbonyl compounds and affected the food taste (White, 1994). The hydroperoxide hydrolysis will create secondary oxidation products (for example, TBARS). Table 2 presents the TBARS analysis results with the addition of antioxidant compounds at various concentrations.

The results in Table 2 shows that TBARS was no significant difference between samples using ascorbic acid at different concentrations in the initial time. However, after 4 weeks of storage, the control sample (not using the antioxidant compound) changed so much, and TBARS was highest. It demonstrated that ascorbic acid prevented the oxidation process. TBARS changing showed a similar tendency with peroxide value. TBARS decreased with increasing ascorbic acid concentration from 0.02 to $0.04 \%$, and it could not be observed TBARS changing at an ascorbic acid concentration above $0.04 \%$. 
Table 1. The ascorbic acid supplementation (\%) on peroxide value of dried fish at different storage times

\begin{tabular}{cccccc}
\hline Ascorbic acid & \multicolumn{5}{c}{ Storage times (weeks) } \\
\cline { 2 - 6 } concentration (\%) & 0 & 1 & 2 & 3 & 4 \\
\hline Non- Ascorbic acid & $0.064 \pm 0.011^{\mathrm{b}}$ & $0.104 \pm 0.017^{\mathrm{b}}$ & $0.141 \pm 0.013^{\mathrm{c}}$ & $0.212 \pm 0.011^{\mathrm{c}}$ & $0.258 \pm 0.012^{\mathrm{c}}$ \\
0.02 & $0.061 \pm 0.009^{\mathrm{b}}$ & $0.080 \pm 0.014^{\mathrm{ab}}$ & $0.108 \pm 0.006^{\mathrm{b}}$ & $0.194 \pm 0.012^{\mathrm{bc}}$ & $0.214 \pm 0.006^{\mathrm{b}}$ \\
0.03 & $0.053 \pm 0.008^{\mathrm{ab}}$ & $0.078 \pm 0.015^{\mathrm{a}}$ & $0.090 \pm 0.004^{\mathrm{a}}$ & $0.171 \pm 0.013^{\mathrm{b}}$ & $0.191 \pm 0.014^{\mathrm{b}}$ \\
0.04 & $0.040 \pm 0.011^{\mathrm{a}}$ & $0.066 \pm 0.013^{\mathrm{a}}$ & $0.081 \pm 0.005^{\mathrm{a}}$ & $0.137 \pm 0.015^{\mathrm{a}}$ & $0.162 \pm 0.015^{\mathrm{a}}$ \\
0.05 & $0.039 \pm 0.012^{\mathrm{a}}$ & $0.060 \pm 0.013^{\mathrm{a}}$ & $0.080 \pm 0.003^{\mathrm{a}}$ & $0.127 \pm 0.013^{\mathrm{a}}$ & $0.157 \pm 0.024^{\mathrm{a}}$ \\
0.06 & $0.038 \pm 0.013^{\mathrm{a}}$ & $0.058 \pm 0.015^{\mathrm{a}}$ & $0.079 \pm 0.005^{\mathrm{a}}$ & $0.115 \pm 0.014^{\mathrm{a}}$ & $0.145 \pm 0.013^{\mathrm{a}}$ \\
\hline
\end{tabular}

Presented data are the mean value of three triplicates \pm standard deviation. Means in the same column with different superscripts are significantly $(\mathrm{p}<0.05)$ different. ns- Not statistically significant at level $\mathrm{p}<0.05$.

Table 2. The effect of ascorbic acid addition (\%) on thiobarbituric acid of dried fish during storage

\begin{tabular}{cccccc}
\hline Ascorbic acid & \multicolumn{5}{c}{ Storage times (weeks) } \\
\cline { 2 - 6 } concentration (\%) & 0 & 1 & 2 & 3 & 4 \\
\hline Non- Ascorbic acid & $4.40 \pm 0.11^{\mathrm{b}}$ & $4.62 \pm 0.14^{\mathrm{b}}$ & $5.33 \pm 0.16^{\mathrm{d}}$ & $5.59 \pm 0.15^{\mathrm{c}}$ & $5.92 \pm 0.14^{\mathrm{c}}$ \\
0.02 & $4.37 \pm 0.13^{\mathrm{bc}}$ & $4.52 \pm 0.21^{\mathrm{ab}}$ & $4.81 \pm 0.16 \mathrm{c}$ & $5.42 \pm 0.13^{\mathrm{bc}}$ & $5.72 \pm 0.16^{\mathrm{bc}}$ \\
0.03 & $4.34 \pm 0.14^{\mathrm{bc}}$ & $4.47 \pm 0.10^{\mathrm{ab}}$ & $4.72 \pm 0.14^{\mathrm{ab}}$ & $5.31 \pm 0.17^{\mathrm{b}}$ & $5.63 \pm 0.19^{\mathrm{b}}$ \\
0.04 & $4.28 \pm 0.06^{\mathrm{bc}}$ & $4.35 \pm 0.12^{\mathrm{ab}}$ & $4.55 \pm 0.06^{\mathrm{ab}}$ & $5.02 \pm 0.12^{\mathrm{a}}$ & $5.29 \pm 0.12^{\mathrm{a}}$ \\
0.05 & $4.26 \pm 0.08^{\mathrm{bc}}$ & $4.32 \pm 0.18^{\mathrm{a}}$ & $4.48 \pm 0.08^{\mathrm{a}}$ & $4.95 \pm 0.18^{\mathrm{a}}$ & $5.23 \pm 0.08^{\mathrm{a}}$ \\
0.06 & $4.20 \pm 0.13^{\mathrm{c}}$ & $4.28 \pm 0.14^{\mathrm{a}}$ & $4.45 \pm 0.16^{\mathrm{a}}$ & $4.82 \pm 0.15^{\mathrm{a}}$ & $5.05 \pm 0.14^{\mathrm{a}}$ \\
\hline
\end{tabular}

Presented data are the mean value of three triplicates \pm standard deviation. Means in the same column with different superscripts are significantly $(\mathrm{p}<0.05)$ different. ns - Not statistically significant at level $\mathrm{p}<0.05$.

Table 3. Effect of ascorbic acid (\%) on total sulfhydryl group of dried fish at different storage times

\begin{tabular}{cccccc}
\hline Ascorbic acid & \multicolumn{5}{c}{ Storage times (weeks) } \\
\cline { 2 - 6 } concentration (\%) & 0 & 1 & 2 & 3 & 4 \\
\hline Non- Ascorbic acid & $30.22 \pm 0.23^{\mathrm{d}}$ & $29.34 \pm 0.18^{\mathrm{c}}$ & $27.37 \pm 0.23^{\mathrm{c}}$ & $24.36 \pm 0.18^{\mathrm{d}}$ & $23.49 \pm 0.23^{\mathrm{c}}$ \\
0.02 & $30.82 \pm 0.13^{\mathrm{c}}$ & $29.84 \pm 0.21^{\mathrm{b}}$ & $28.23 \pm 0.13^{\mathrm{b}}$ & $27.45 \pm 0.26^{\mathrm{c}}$ & $25.18 \pm 0.25^{\mathrm{b}}$ \\
0.03 & $30.91 \pm 0.17^{\mathrm{c}}$ & $30.38 \pm 0.32^{\mathrm{b}}$ & $28.69 \pm 0.17^{\mathrm{b}}$ & $28.29 \pm 0.25^{\mathrm{c}}$ & $26.21 \pm 0.13^{\mathrm{b}}$ \\
0.04 & $31.60 \pm 0.14^{\mathrm{b}}$ & $31.20 \pm 0.39^{\mathrm{a}}$ & $29.63 \pm 0.24^{\mathrm{a}}$ & $28.98 \pm 0.32^{\mathrm{b}}$ & $28.17 \pm 0.28^{\mathrm{a}}$ \\
0.05 & $31.81 \pm 0.19^{\mathrm{ab}}$ & $31.34 \pm 0.22^{\mathrm{a}}$ & $29.85 \pm 0.13^{\mathrm{a}}$ & $29.25 \pm 0.05^{\mathrm{a}}$ & $28.25 \pm 0.17^{\mathrm{a}}$ \\
0.06 & $32.19 \pm 0.17^{\mathrm{a}}$ & $31.47 \pm 0.19^{\mathrm{a}}$ & $30.27 \pm 0.18^{\mathrm{a}}$ & $29.70 \pm 0.16^{\mathrm{a}}$ & $28.37 \pm 0.31^{\mathrm{a}}$ \\
\hline
\end{tabular}

Presented data are the mean value of three triplicates \pm standard deviation. Means in the same column with different superscripts are significantly $(\mathrm{p}<0.05)$ different. ns- Not statistically significant at level $\mathrm{p}<0.05$.

Table 4. The effect of ascorbic acid addition (\%) on available sulfhydryl group of dried fish at different storage times

\begin{tabular}{cccccc}
\hline $\begin{array}{c}\text { Ascorbic acid } \\
\text { concentration (\%) }\end{array}$ & 0 & 1 & 2 & 3 & 4 \\
\cline { 2 - 6 } Non- Ascorbic acid & $11.42 \pm 0.20^{\mathrm{d}}$ & $11.09 \pm 0.17^{\mathrm{d}}$ & $10.21 \pm 0.14^{\mathrm{d}}$ & $9.43 \pm 0.13^{\mathrm{d}}$ & $8.52 \pm 0.21^{\mathrm{d}}$ \\
0.02 & $11.65 \pm 0.14^{\mathrm{cd}}$ & $11.36 \pm 0.11^{\mathrm{cd}}$ & $11.02 \pm 0.13^{\mathrm{c}}$ & $10.35 \pm 0.36^{\mathrm{c}}$ & $9.38 \pm 0.23^{\mathrm{c}}$ \\
0.03 & $11.68 \pm 0.27^{\mathrm{bcd}}$ & $11.48 \pm 0.22^{\mathrm{bc}}$ & $11.22 \pm 0.17^{\mathrm{bc}}$ & $10.69 \pm 0.25^{\mathrm{bc}}$ & $9.90 \pm 0.21^{\mathrm{b}}$ \\
0.04 & $11.94 \pm 0.14^{\mathrm{abc}}$ & $11.78 \pm 0.19^{\mathrm{ab}}$ & $11.43 \pm 0.14^{\mathrm{ab}}$ & $10.95 \pm 0.12^{\mathrm{ab}}$ & $10.33 \pm 0.28^{\mathrm{a}}$ \\
0.05 & $12.02 \pm 0.19^{\mathrm{ab}}$ & $11.84 \pm 0.23^{\mathrm{a}}$ & $11.56 \pm 0.13^{\mathrm{a}}$ & $11.05 \pm 0.31^{\mathrm{ab}}$ & $10.40 \pm 0.17^{\mathrm{a}}$ \\
0.06 & $12.08 \pm 0.20^{\mathrm{a}}$ & $11.89 \pm 0.17^{\mathrm{a}}$ & $11.63 \pm 0.14^{\mathrm{a}}$ & $11.16 \pm 0.13^{\mathrm{a}}$ & $10.47 \pm 0.21^{\mathrm{a}}$ \\
\hline
\end{tabular}

Presented data are the mean value of three triplicates \pm standard deviation. Means in the same column with different superscripts are significantly $(\mathrm{p}<0.05)$ different. ns- Not statistically significant at level $\mathrm{p}<0.05$.

Tables 3 and 4 show the limitation of protein denaturation during storage by adding antioxidant compounds. The increase of ascorbic acid concentration reduced the degree of oxidation of dried fish. The results were no significant difference between samples adding ascorbic acid from 0.04 to $0.06 \%$. The addition of $0.04 \%$ ascorbic acid in the soaking process was selected to store dried snakehead fish products with the moisture content of $20 \%$. 


\section{Conclusion}

This study showed that the drying time in dried snakehead fish processing with the addition of glycerol $3 \%$ and $4 \%$ sorbitol was $26.21 \mathrm{hrs}$. Dried snakehead fish had a salt content of $6.04 \%$, a water activity of 0.576 . The addition of ascorbic acid controlled lipid and protein oxidation in dried snakehead fish. Peroxide value, TBARS, total sulfhydryl group, and available sulfhydryl group of dried snakehead fish supplemented with $0.04 \%$ ascorbic acid were $0.040 \mathrm{mEq} / \mathrm{kg}$ lipid, $4.28 \mathrm{mg} \mathrm{MDA} /$ $\mathrm{kg}, 31.60 \mathrm{mmol} / \mathrm{g}$ protein, and $11.94 \mathrm{mmol} / \mathrm{g}$ protein (dry material), respectively.

\section{Acknowledgments}

The authors acknowledge Can Tho University in providing facilities for the smooth running of this study.

\section{References}

Adamson, E.A.S., Hurwood D.A. and Mather P.B. (2010). A reappraisal of the evolution of Asian snakehead fishes (Pisces, Channidae) using molecular data from multiple genes and fossil calibration. Molecular Phylogenetics and Evolution, 56(2), 707-717. https://doi.org/10.1016/ j.ympev.2010.03.027

Barrett, H.A., Briggs, J., Richardson, M. and Reed, T. (1998). Texture and storage stability of processed beefsticks asa by glycerol and moisture levels. Journal of Food Science, 63(1), 84-87. https:// doi.org/10.1111/j.1365-2621.1998.tb15681.x

Chanasattru, W. (2008). Influence of water-soluble polyols on globular protein functionalities. Amherst, Massachusetts, USA: University of Massachusetts Amherst, PhD Thesis.

Ellman, G.D. (1959). Tissue sulfhydryl groups. Archives of Biochemistry and Biophysics, 82(1), 70-77. https://doi.org/10.1016/0003-9861(59)90090-6

Fennema, O.R. (Ed.) (1996). Water and ice. In Food Chemistry. 3rd ed., p. 17 - 94. New York, USA: Marcel Dekker.

Hossain, M.K., Latifa G.A. and Rahman M.M. (2008). Observations on induced breeding of snakehead murrel, Channa striatus (Bloch, 1793). International Journal of Sustainable Crop Production, 3(5), 6568.

Hu, F.B., Bronner L. and Willett, W.C. (2002). Fish and omega-3 fatty acid intake and risk of coronary heart disease in women. Journal of the American Medical Association, 287(14), 1815-1821. https:// doi.org/10.1001/jama.287.14.1815
Iseya, Z., Kubo, T. and Saeki, H. (2000). Effect of sorbitol on moisture transportation and textural change of fish and squid meats during curing and drying processes. Fisheries Science, 66(6), 11441149. https://doi.org/10.1046/j.14442906.2000.00181.x

Lemon, D.W. (1975). An improved TBA test for rancidity. Canada: Fisheries and Marine Service.

Michael, C.Q. and Oscar A.P. (2003). Fat characterization. In Nielsen, S.S. (Ed.). Food Analysis Laboratory Manual, p. 103-113. USA: Springer.

Nguyen, V.M. and Tran T.T. (2008). Effect of different solutes on water activity of dried Snakeskin fish (Trichogaster Pectoralis Regan). Can Tho University Journal of Science, 10, 151-160.

Nguyen, X.D. and Nguyen A.T. (2013). Screening of plants with antioxidant activity and application in fishery processing. Can Tho University Journal of Science. Part B: Agriculture, Fisheries and Biotechnology, 28, 59-68.

Park, D. and Xiong Y.L. (2007). Oxidative modification of amino acids in porcine myofibrillar protein isolates exposed to three oxidizing systems. Food Chemistry, 103(2), 607-616. https://doi.org/10.1016/ j.foodchem.2006.09.004

Rao, B.Y.K. and Bandyopadhyay C. (1983). Lipid composition of salted sun-dried Indian Mackerel (Rastrelliger kanagurta). Journal of Food Science and Technology, 20(3-4), 62-64.

Serdaroglu, M. and Felekoglu, E. (2005). Effects of using rosemary extract and onion juice on oxidative stability of sardine (Sardina pilchardus) mince. Journal Food Quality, 28(2), 109-120. https:// doi.org/10.1111/j.1745-4557.2005.00016.x

Sullivan J.C., Budge S.M. (2012). Fish oil sensory properties can be predicted using key oxidative volatiles. European Journal of Lipid Science and Technology, 114(5), 496-503. https:// doi.org/10.1002/ejlt.201100330

Thorarinsdottir, K.A., Arason S., Bogason, S.G. and Kristbergsson, K. (2004). The effect of various salt concentrations during brine curing of cod (Gadus morhua). International Journal of Food Science and Technology, 39(1), 79-89. https://doi.org/10.1046/ j.0950-5423.2003.00757.x

Tokur, B. and Korkmaz, K. (2007). The effects of an iron-catalyzed oxidation system on lipids and proteins of dark muscle fish. Food Chemistry, 104 (2), 754-760. https://doi.org/10.1016/ j.foodchem.2006.12.033 
Tran, B.L., Tran, T.T., Dang, H.T. and Nguyen, V.M. (2019). Influence of brining and frozen storage on quality changes in the muscle of snakehead fish at post-mortem stages. Journal of Agriculture and Rural Development, 3-4, 146-154.

Tran, D.D., Shibukawa, K., Nguyen, T.P., Ha, P.H., Tran, X.L., Mai, V.H. and Kenzo, U. (2013). Fishes of the Mekong Delta, Viet Nam. Can Tho University Publishing House, 124-126.

Uçak, I., Özogul, Y. and Durmus, M. (2011). The effects of rosemary extract combination with vacuum packing on the quality changes of Atlantic mackerel fish burgers. International Journal of Food Science, 46(6), 1157-1163. https://doi.org/10.1111/j.13652621.2011.02610.x 